\title{
Green Practices for Global Supply Chains in Diverse Industrial, Geographical, and Technological Settings: A Literature Review and Research Agenda
}

\author{
Maria Giuffrida * and Riccardo Mangiaracina \\ Department of Management, Economics, and Industrial Engineering, Politecnico di Milano, 20156 Milan, Italy; \\ riccardo.mangiaracina@polimi.it \\ * Correspondence: maria.giuffrida@polimi.it
}

Received: 27 October 2020; Accepted: 1 December 2020; Published: 4 December 2020

check for

updates

\begin{abstract}
With the rise in global consumption and the consequent intensive demand for global resources, the attention of scholars and practitioners towards greener supply chains has grown over the years. In this context, this study has two main aims. The first is to offer an up-to-date literature review of the ways in which sustainability is pursued in diverse settings, based on the sector, the geographical area, and the level of adoption of digital technologies of a company. The second aim is to identify the research gaps in this field, and to suggest directions for future investigations. The results of the structured literature review reveal that, although developed and developing countries tend to focus on different types of sustainable interventions, three factors are consistently considered to be crucial for the success of a sustainable initiative in global supply chains. These factors are the collaboration along the supply chain, the commitment of the top management, and the presence of environmentally-oriented policies or regulations. These three factors complicate the decision-making process that is needed to implement sustainable practices. Therefore, we suggest ways in which to design future research that better capture the real challenges of making environmentally conscious decisions, leveraging on the concepts of the Intertwined Supply Network (ISN) and the cognitive frame.
\end{abstract}

Keywords: environmental sustainability; global supply chain; developing economies; developed economies; digital technology; literature review; decision making; industry; cognitive frame; intertwined supply network

\section{Introduction}

With the rise in global consumption and the consequent intensive demand for global resources, significant challenges have been posed to the sustainable development of many countries across the globe. In response to these threats, several directives have been issued over the last few years by national and supranational organisations (e.g., the United Nations, the European Union) to push towards more sustainable practices in areas encompassing resource consumption, emissions reduction, and waste management, and to encourage the implementation of circular economy models $[1,2]$. Alongside the institutional policies, several world-leading firms have launched sustainable initiatives for their supply chains. For instance, Apple established a set of supplier responsibility standards, and Unilever implemented a 'sustainable living plan' in the early 2010s [3]. However, despite the numerous initiatives, the achievement of successful results in terms of sustainability is still very challenging, especially if the companies are multinationals. In this case, the distance between buyers and suppliers located in different markets, the cultural differences, and the dissimilar expectations in terms of sustainability goals still represent crucial barriers [4-6]. The amount of complexity further increases if companies operate in emerging economies, where there is a tendency to compromise 
environmental standards in favour of economic growth, and due to the lack of environmental and social laws [7]. Among the most challenging aspects of managing (or belonging to) a global supply chain is the lack of visibility beyond first-tier suppliers or customers, and the need to comply with local habits and regulations, which may change across countries and regions [6].

Despite the abundant presence of literature contributions on sustainability in global contexts, e.g., Hong et al., Choi and Hong, Wu and Pullman, Koberg and Longoni, 2015 [3,6], there are no clear indications on what topics are covered to address sustainability in the multitude of contexts that might possibly characterise a global supply chain. The existing contributions and reviews in this field can be classified into two main categories. On one side, we find general contributions that do not focus on a specific country or industry, and which therefore provide broad observations, e.g., Ahmadi et al., Ebinger and Omondi [8,9]; on the other side, there are studies focused on a single geographical area or industrial sector which provide specific — but not always generalizable—insights, e.g., Mitra and Gaur, Giuffrida et al. [10,11]. This study aims to bridge these two opposing clusters of contributions by reuniting them in the same review paper that specifically addresses sustainability in different settings. More precisely, this research has two main objectives.

The first is to shed some light on the ways in which sustainability can be pursued in diverse contexts by offering an up-to-date literature review. The diversity of the settings, in our paper, is measured by the sector, the country/geographical area, and the level of adoption of the digital technologies of a company. In this light, we extend, to a global scope, some preliminary research that was already focused on the sustainability implications of digital technology applications to national businesses or supply chains [12]. This helps provide more in-depth insights into reasonable and context-related sustainability practices. The second objective is to identify and describe the possible research directions in this field.

We reach the above-mentioned general aims by addressing two main Research Questions (RQs):

RQ1a. What are the key research streams described in the literature with reference to the environmental sustainability of global supply chains?

RQ1b. Do they differ based on contextual factors, such as the industry, the country of reference, and the use of digital technologies?

RQ2. What research gaps are present in this field, and how could future studies address such gaps?

In order to address the above-mentioned RQs, a structured literature review was conducted. The systematic approach was selected because it allows us to compare and synthesise a large body of knowledge and develop future research ideas [13]. The main contributions of this study are the systematization and discussion of papers based on novel classification variables, and the presentation of a specific framework for future research that could help both scholars and practitioners to better understand the challenges behind the implementation of green supply chain practices.

The paper consists of five main sections. The next section describes the methodology, the third section elucidates the results of the review, the fourth section discusses the main implications of the review and identifies directions for future research, and the last section concludes.

\section{Methodology}

This review covers the scientific contributions of the past eight years. This rather restricted timeline occurred because of a combination of factors. On the one hand, despite the fact that the digital revolution is claimed to have started in the 1980s, digital technologies' most extensive adoption is a more recent phenomenon, relatively speaking. Digital technologies, such as the Internet of Things, Big Data, Artificial Intelligence, and Blockchain, started to be used in most countries of the world, including developing countries, in the 2010s [14]. On the other hand, there has been a significant increase in the attention towards sustainability matters in the same recent timeframe. For instance, 
the 17 Sustainable Development Goals (SDGs), which represent an imperative call for action by both developed and emerging countries, were defined only in 2015 [15].

In line with recent literature reviews published in supply chain management journals, e.g., Giuffrida et al., Ren et al., Tasdemir and Gazo [16-18], a precise sequence of steps was followed in order to deliver this research, namely a literature search, a literature analysis and description, and gap identification. These phases are described in the following paragraphs.

\subsection{Literature Search}

In the literature search phase, we used the international bibliographic databases Scopus and ISI Web of Knowledge, as well as the science search engine Google Scholar and cross-reference snowballing in order to retrieve pertinent contributions [19-21]. More precisely, the search was organised as follows.

First, we defined a specific set of words that are relevant for our research field, and which cover the main aspects we wish to analyse, namely the sustainability practices in global supply chains pertaining to different sectors and countries, and possibly using different supporting technologies. Examples of these words include "environmental sustainability", "digital technology", "global supply chain", "industry", and "developing markets". These keywords were initially inputted in the search string and connected by the operator "AND", because they refer to all of the elements we hope to find within each contribution.

Second, for each main keyword, we identified a set of alternatives that represent either a synonym or a better specification of the primary word. For instance, "green" was used as a synonym of "environmental sustainability"; "global value chain" represented an alternative to "global supply chain"; "automotive", "fashion", and "food", etcetera, were detailed specifications of the "industry". Similarly, words like "Asia", "Europe" "Africa", "blockchain", "cloud", "big data", and "internet of things" were used as better specifications, respectively, for the geographical and technological dimensions. All of these words were connected by the operator "OR", because they are mutually exclusive and should be searched for as an alternative to each other. For explanatory purposes, an example of a search string inputted into Scopus is provided below:

TITLE-ABS-KEY(((environment* sustainab*) OR (green)) AND ((global supply chain*) OR (global value chain*)) AND ((develop* countr*) OR (develop* market*) OR (emerging countr*) OR (develop* econom*)OR (Asia*) OR (Europe*) OR (Asia Pacific) OR (America*) OR (Africa*)) AND ((industr*) OR (sector*) OR (automotive) OR (electronics) OR (fashion) OR (textile) OR (food) OR (agriculture) OR (luxury) OR (pharma)) AND ((digital technolog*) OR (digital innovation) OR (blockchain) OR (internet of things) OR (RFId) OR (e-commerce) OR (big data) OR (artificial intelligence) OR (industry 4.0) OR (cloud) OR (mobile) OR (drone)))

The use of the asterisk $(*)$ near to words like "sustainab" purpose of catching relevant keywords in any combination they may appear (e.g., as a noun or adjective, in the singular or plural form). For instance, "sustainab" includes both "sustainability" and "sustainable"; "countr" stands for both "country" and "countries"; "develop" catches both "developed" and "developing", and so on.

The operator "TITLE-ABS-KEY" indicates that the selected words needed to appear in the most important sections of the papers, namely the title, the abstract, or the keywords. As shown in the results section of this manuscript, not all of the relevant papers cover simultaneously all of the main aspects we wanted to investigate. For instance, some papers describe country- and industry-specific practices that do not rely on any digital technology. Therefore, we repeated multiple search runs, substituting some "AND" operators with "OR". We also used other databases (i.e., ISI and Google Scholar).

Third, a backward snowballing approach was followed, as suggested by the extant literature [20,21], in order to capture relevant knowledge that, for whatever reason, may not have been indexed in our databases, or that we may have missed due to the keyword selection. 
Fourth, we defined the inclusion/exclusion criteria (e.g., we considered only papers written in English, focused on environmental sustainability, published in Journals ranked in Quartile 3 or higher according to the leading scientific journal ranking platform SCImago). These criteria are detailed in the Preferred Reporting Items for Systematic Reviews and Meta-Analyses (PRISMA) flow diagram presented in Appendix A. Starting with an initial dataset of 95 papers (excluding duplicates), we arrived at the final selection of 66 papers, which represent the most suitable contributions for this review, and are discussed in the results section.

\subsection{Literature Analysis}

In the literature analysis phase, the selected contributions were examined deeply and classified based on a set of relevant variables, i.e., the publication year, journal, adopted methodology, as is commonly carried out in the extant literature reviews, e.g., [16-18]. Regarding the content, we recorded the country/region of reference, the industry of reference, the main processes impacted by the solution (e.g., production, distribution), and the level of adoption of digital technology. We also analysed the specific initiative or issue described in the paper. By collecting a structured amount of information for each article, we were able to categorise the publications systematically and present them conveniently into classification tables, as well as being able to identify key discussion points and gaps more easily.

\subsection{Identification of Gaps and Hints for Future Research}

In the last stage, the gap identification emerged rather naturally from the analysis of the extant literature. More specifically, starting from the most relevant identified gaps and topics, the proposal of a future research framework and questions was postulated by the selection of the issues that we considered to be more significant from a global supply chain sustainability perspective.

\section{Results}

\subsection{Features of the Articles}

Figure 1 shows the time evolution of the papers analysed in this review. Most of the contributions are very recent, with over $80 \%$ of papers being published from 2018 onwards, and 50\% in 2020 only. This result confirms that the specific perspective taken in this study is rather nascent but growing exponentially due to an increasing interest in sustainability and digitalisation aspects. Not surprisingly, 2020 is also the year when the European Green Deal came into action, and several environmental-friendly laws (e.g., to reduce plastic consumption) were issued in both developed and emerging countries, such as France, Thailand, Palau, and the USA [22,23]. In order to focus on the highest quality research, $90 \%$ of the contributions were published in journals ranked Q1 or Q2. No publications are below Q3, and no conference proceedings are considered. Most papers belong to sustainability-centred journals, namely the 'Journal of Cleaner Production' (14\%), 'Sustainability' (9\%), and 'Resources, Conservation and Recycling' (6\%). The remaining are scattered among approximately 40 journals focused on supply chain, logistics and production management (e.g., 'International Journal of Logistics Management', 'International Journal of Production Economics') or on some specific sectors (e.g., 'Agricultural and Food Economics', 'Clothing and Textiles Research Journal', 'Marine Policy'). 


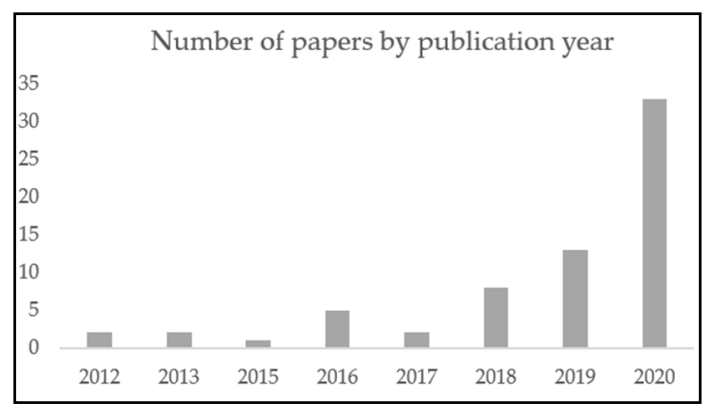

Figure 1. Number of papers by publication year.

Figure 2 presents the main methods used in the papers based on Meixell and Norbis [24]. As shown, the general review-presenting evidence from the literature, practitioner reports and other secondary data-is the most common method (33\%). Among the papers in this cluster, we find Lu et al. presenting a comparison between reuse practices for Waste Electrical and Electronic Equipment in China and Europe [25], while Kusch-Brandt proposes a list of sustainability lessons learned for the food industry [26].

Following this, we find empirical papers presenting either case studies $(24 \%)$ or surveys $(14 \%)$. In this cluster, for instance, Chikudza et al. [27] developed a survey to understand the incentives and challenges linked to the implementation of a labelling system to ensure the traceability and sustainability of seafood products in Europe. In contrast, Castro-Nunez et al. [28] presented a study to show that the deforestation problem in Colombia is not linked, as many assume, to commodities production, such as cocoa plants.

Another $17 \%$ of the publications propose analytical models, e.g., Wiedemann et al. [29], who performed a Life Cycle Assessment of the entire Supply Chain for a woollen garment. Finally, $6 \%$ of contributions propose conceptual models in the electronics, food, and automotive industries [30-32], while the remaining $6 \%$ present literature reviews on the governance issues of green value chains and e-waste legislation [33-35]. No specific literature reviews on the topic selected for this study, i.e., the analysis of context-related sustainable practices, were found.

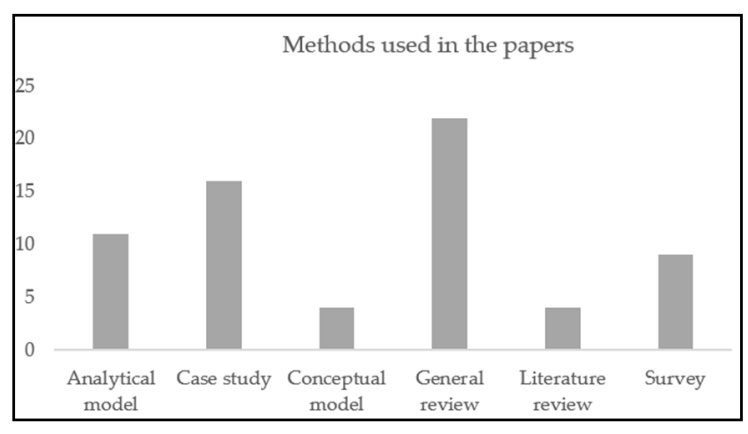

Figure 2. Methods used in the papers.

\subsection{RQ1: Current Sustainability Research Trends in Global Supply Chains}

In order to answer our RQ1, we classified the papers taking into account the main context variables considered in this research. We started by considering the country in which a given supply chain activity takes place, and the industry to which the company belongs. On the industry side, we found that the retrieved contributions may belong to the Agrifood, Automotive, Electronics, High-Tech, Logistics, Pharmaceutical or Apparel businesses. Based on the country, we distinguished between research that is focused on developed markets or developing ones. By looking at the paper distribution summarised in Table 1, we can observe that all of the papers selected for the review present an industry focus, with automotive and apparel being the most represented. However, not all the contributions 
are focused from a geographical viewpoint (i.e., they are only focused on developed or developing markets). Over $40 \%$ of contributions analyse both developed and developing countries, and were labelled as papers with a global scope. Among the papers that analyse a specific country or region, emerging markets prevail, especially China, India, and Brazil.

Comparing the results by industry, we can observe that the electronics, high-tech, pharmaceutical and logistics sectors are not totally covered from a geographical perspective in the literature, as no papers were found in some geographical contexts for these industries.

Regarding the electronics, high tech and pharma industries, the papers focus more on emerging markets. In the high-tech and consumer electronics industries, for instance, many papers are concentrated on a limited number of Asian countries (e.g., China, Taiwan and India), because these regions present both lower costs and higher specialisation for the production of these product categories. Therefore, a centralisation of the manufacturing base and the related research in these specific areas-with China occupying a dominant position-has occurred.

Regarding the pharmaceutical sector, we find contributions mainly from the Indian market, because this country is recognised to have better capabilities in formulation development, drug manufacturing, and final distribution towards the US and European markets. At the same time, many problems linked to the pollution generated by drug manufacturing have emerged in this area, which explain a more massive presence of sustainability studies for this country.

Finally, regarding the logistics and transport industry, we found some contributions only in the developed countries cluster, mainly referring to the German market because this country is a leader in sustainable logistics, and it has a National Sustainability Strategy that recognises the crucial role of logistics [36]. Conversely, emerging economies' logistics landscapes are less mature, and are still characterised by fragmentation. Therefore, sustainability issues are not yet covered in these areas.

The remaining industries (agri-food, automotive and apparel) are, instead, relatively equally studied in both developed and developing economies, and are addressed in most of the retrieved studies.

Table 1. Distribution of papers by industry and country focus.

\begin{tabular}{ccccc}
\hline Industry & Developed Countries & Developing Countries & Global & Total \\
\hline Agri-food & $5 \%$ & $6 \%$ & $6 \%$ & $17 \%$ \\
Automotive & $9 \%$ & $12 \%$ & $15 \%$ & $36 \%$ \\
Electronics & - & $5 \%$ & $5 \%$ & $10 \%$ \\
High-tech & - & $2 \%$ & - & $2 \%$ \\
Logistics/Transport & $2 \%$ & - & - & $2 \%$ \\
Pharmaceutical & - & $3 \%$ & $6 \%$ & $9 \%$ \\
Textile, apparel and & $8 \%$ & $9 \%$ & $9 \%$ & $26 \%$ \\
luxury & $23 \%$ & $36 \%$ & $41 \%$ & $100 \%$ \\
Total & & $3 \%$ & & \\
\hline
\end{tabular}

The table presents the portion of papers falling in each category, calculated according to the total number of papers.

\subsubsection{Sustainability Practices in Emerging Economies}

Among the studies based on developing countries, there is a significant focus on the consideration that sustainability practices have much higher chances of being successful if effective cooperation mechanisms are in place. Indeed, sustainability initiatives depend on multiple actors. Accordingly, Villa et al. [37] describe established collaboration-based processes for the development of green innovations in the Brazilian fashion industry, such as new product development derived from confection leftovers and the creation of a reverse logistics chain for used clothes. Pacheco et al. [38] identify effective governance systems to win over the antagonisms between public rules and private standards. Similarly, Jeong et al. [39] stress the importance of strategic alliances in the Asian eco-friendly automotive industry. Jeong, Ko, Chavez and Sharma [40] provide information on the willingness of car owners in Mexico to cooperate with car manufacturers to support green initiatives for car component recycling. Likewise, in the electronics industry, some references to cooperation are present, such as 
Wong [30], that underline the importance of knowledge sharing for sustainable innovation. A slightly diverse perspective is the one offered by Bryceson and Ross [41], who describe the importance of collaboration in terms of informal social relationships (in contrast with formalised agreements) for sustainability advancement in complex Asian agri-food supply chains.

Another stream of research focuses on the motives or barriers to sustainability implementation. For instance, Bhaskar et al. [42] describe the effect of e-waste management rules in India on the implemented practices: while the regulations create an increase in producers' responsibility towards waste management, the same type of commitment is not induced in consumers, leading to a mostly-ineffective implementation of the sustainability practices. Law and Gunasekaran, instead, focus on the motivators of sustainability initiatives in Hong Kong high-tech industry [43]. The authors identify—in both top management commitment and infrastructure development- the main enablers of sustainable practices. Kumar et al. [44] arrive at a similar conclusion in the Indian automotive context by finding that companies' top management is the main critical success factor for sustainable manufacturing implementation. Cardoso et al., instead, discover significant relationships between the size of a company and the motivation to opt for a specific type of sustainable production practice in the fashion industry, based on a list of 31 clean production practices [45]. For instance, they find that small companies are motivated mainly by cost reduction. Medium-sized companies are pushed to implement sustainable production by the need to stay competitive, especially in the global market. Larger companies are the leading adopters of sustainable practices, and are motivated by the willingness to preserve or improve their brand image and increase their market share.

On top of that, Cardoso et al. [46] also find a relationship between the implementation of clean production practices and specific SDGs. More precisely, they show that clean production contributes to SDG 9 (Industry, Innovation and Infrastructure), 12 (Responsible Production and Consumption) and 15 (protection of Life on Land). Overall, the main drivers for the implementation of sustainable practices are always of economic or legal nature. More specifically, $26 \%$ of the of the contributions focused on emerging markets present initiatives that are mainly driven by legal requirements, while economic or performance goals drive the remaining $74 \%$. Being more sustainable does not seem to be the primary objective in any of the initiatives of this cluster of papers. Instead, it seems to be an additional benefit that is achieved on top of the real intended goals. These practices are mainly motivated by cost reduction, brand image improvement or legal compliance.

A third research area is the one focusing on environmental upgrading initiatives, i.e., the process by which companies aim at repositioning themselves along the value chain in order to increase their sustainability benefits. By examining the apparel value chain in Sri Lanka, for instance, Khattak et al. [47] find that environmental upgrading happens mainly to leading firms which upgrade only with core suppliers in order to maintain their environmental performance while reducing operational costs.

Last, by focusing on industry-specific initiatives, we found that-in the Pakistani apparel and textile sector-Abbas et al. [48] examine the most appropriate options for the sustainability of resources, energy, and water (e.g., using solar energy or biomass from cotton crop waste, implementing wastewater technologies, pushing for regulatory interventions). In the automotive industry, Li focuses on the needed development of new energy vehicles and their dependence on effective policy implementation [49]. Similarly, Choi and Rhee propose a recycling scheme for end-of-life battery of electric vehicles in Korea [50]. In contrast, Ruben et al. [51] suggest the implementation of a Lean Six Sigma approach in the Indian automotive components industry. Regarding the pharmaceutical industry, Veleva et al. [52] present a survey showing that Indian companies rely on the treatment and disposal of wastewater instead of resource usage reduction. Regulatory issues and time constraints when delivering the drugs are the two most significant barriers for the broader adoption of green materials in India. Cost savings and environmental regulations are, conversely, the main drivers. Finally, in the agri-food sector, Kaczan et al. [53] examine the problem of overfishing in Pakistan, suggesting more effective management models and policy interventions. 


\subsubsection{Sustainability Practices in Developed Economies}

Looking at the contributions that examine sustainability issues in developed markets' supply chains, we found some differences with the developing economies presented above.

First, there is more significant concern and interest, among developed countries, for circular economy models. As consumers in advanced economies are becoming increasingly conscious about the sustainability aspects in their purchasing decisions, companies are evolving towards the application of circular economy principles. These postulate a transition from traditional production and consumption models to others that minimise waste and pollution, and encourage recycling and the regeneration of natural systems [54]. In this field, Gazzola et al. describe circular initiatives in the fashion industry, such as the use of innovative technologies that can transform textile waste into new fibres. However, the authors recognise that the industry is still far from being circular, due to logistics problems and the lack of comprehensive solutions and adequate infrastructure [54]. Moore et al. explore, instead the potential of circular models to manage the reuse of end-of-life batteries in Germany, finding multiple benefits, such as the increased diffusion of renewable energy systems [55].

Second, there is an interesting research stream on sustainability assessment, which seems to be lacking in studies relating to developing countries. For instance, Schiessl et al. develop a model to integrate environmental impact assessment and environmental performance indicators into the global supplier selection processes in the steel industry [56]. Bobba et al., similarly, present a method to support environmental performances assessment based on second-use electric vehicle batteries [57]. Mair-Bauernfeind et al., instead, propose a combination of methods to quantify the environmental effects of introducing wood-based materials, instead of steel, into the components of the automotive industry [58].

Third, when looking at the processes described in the papers, we found that developed market-based papers tend to present research that analyses environmental sustainability applications across distinct supply chain phases or activities, e.g., product development [58,59], supplier relationship management [56,60], production [61], logistics and distribution [55,57,62,63], and customer relationship management $[27,64]$. In contrast, research related to developing economies is focused mainly on papers that deal with the supply chain as a whole, and there is no or little focus on specific supply chain processes, e.g., Messner et al., Villa et al., Bryceson and Ross [31,37,41].

However, there are also some similarities across the research related to developed and developing markets. The main commonality is that, even for developed countries, there are some studies on the barriers and the enablers of environmental sustainability practices. For instance, Chikudza et al. [27] discuss the incentives and challenges linked to the adoption of ecolabels in the aquaculture industry in Europe. Secondly, the existence of appropriate regulations and policies is a crucial element in the sustainability-oriented decisions for companies in developed markets [60], together with the economic incentives. Indeed, over $80 \%$ of the contributions reveal that sustainable practices are motivated by the expected increase in revenues generated by the price premium applied to green products or the cost savings linked to an optimised use of resources. Only $10 \%$ of the papers center the achievement of environmental benefits as a primary (and not ancillary) goal. No exceptions to this trend are registered across the different industries.

\subsubsection{Sustainability Practices in Global Economies}

The last cluster analysed in this section is the one formed by papers that do not specifically focus on a selected geographical area, but rather tackle the environmental sustainability issue in a broader sense. As shown in Table 1, this is the largest group of papers, accounting for $41 \%$ of the selected list of papers. Many articles belonging to this cluster present general overviews on global trends, [65-70], or literature reviews [33-35]. This further confirms that no other reviews analyse specific geographical and industry contexts like the present study.

In this group of papers, there is also a large share of studies on environmental performance assessment, which are also present in developed economy-based papers. For instance, Ferreira et al. [71] 
propose a survey-based evaluation of the environmental benefits of cleaner production adoption in the textile and apparel industry. On a similar note, Wiedemann et al. [29] calculate the impacts of using woollen garments in textile manufacturing. Kushwaha and Sharma instead verify the existence of a positive relationship between green practice implementation in the automotive industry and the impact on both firm performance and sustainable development [72]. Similarly, other authors, e.g., Farrias et al., Cucchiera et al., Cherrafi et al. [73-75], focus on green performance assessment in the automotive sector.

Even in this cluster, the role of the drivers and barriers of sustainable initiatives is discussed—for instance, by Veleva and Cue [76,77], Koenig et al. [78], and Dranev et al. [79]—in the pharmaceutical industry.

Regarding the examined processes, we found that most papers take, overall, a generic perspective on the supply chain, with only a few contributions examining specific phases or activities. In this aspect, papers with global geographical scope are more similar to papers described in the developing countries section.

Finally, in this cluster of papers, environmental sustainability practices are not primarily driven by purely ecological interests. As has already been observed for both developed and developing markets, a significant set of studies (accounting for $82 \%$ of the papers) is motivated by economic gains or legal compliance motives (14\%). Only $4 \%$ identify environmental sustainability as the core driver of the implemented practice.

\subsubsection{The Role of Technology}

Despite the hype of interest that has characterised digital technologies in the past few years, they still play a marginal role in supporting the environmental sustainability practices of global supply chains. As Table 2 testifies, only $17 \%$ of the contributions, i.e., 11 papers, deal with digital technology applications in this field. Approximately half of them refer to the "global" cluster. Only $3 \%$ refer to developing markets.

Table 2. Distribution of papers by the use of digital technology and country focus.

\begin{tabular}{ccccc}
\hline Digital Technology Adoption & Developed Country & Developing Country & Global & Total \\
\hline No & $18 \%$ & $33 \%$ & $32 \%$ & $83 \%$ \\
Yes & $5 \%$ & $3 \%$ & $9 \%$ & $17 \%$ \\
Total & $\mathbf{2 3} \%$ & $\mathbf{3 6} \%$ & $\mathbf{4 1 \%}$ & $\mathbf{1 0 0} \%$ \\
\hline
\end{tabular}

The table presents the portion of papers falling into each category, calculated on the total number of papers.

Among the papers dealing with a developing economy, we found Rane et al. [80], who discuss the benefits of adopting a Blockchain-Internet of Things integrated architecture in the automotive industry. Considering the importance of suppliers and customers to the achievement of effective green supply chain practices, the paper leverages technology applications to show the ways in which these can facilitate supply chain integration.

Rahman et al. [81], instead, focusing on emerging markets, analyse the barriers to the adoption of biotechnology, which is more sustainable than chemicals, in textile processing. They identify, for instance, high costs and the lack of long-term stability of the materials.

Regarding the papers in the domain of the developed markets, we found big data applications that were used to measure and increase energy efficiency, and reduce water and resource consumption, waste, and emissions in the German automotive sector [61]. Fulton and Lee focus instead on sustainable initiatives in the fashion online retail sector [63], whereas Wei et al. [62] provide an overview of digital technology applications in logistics and transportation. Among these, we found Internet of Things (IoT) and Radio Frequency Identification (RFId) to monitor logistics processes, and blockchain to guarantee security and traceability. 
Finally, the remaining papers are mostly focused on Industry 4.0 applications in the agriculture [82], apparel [83], and automotive industries [84,85]. Industry 4.0, representing a paradigm of technologies enabling smart manufacturing processes, is the main set of digital solutions investigated in these papers, followed by IoT and RFId and, to a lower extent, big data and blockchain.

\subsection{RQ2: Research Gaps}

Considering the presented review, several gaps can be identified in the extant body of literature. First, the literature is still quite fragmented when it comes to context-specific content. As reported in Table 1, there are many missing values at the intersection of country and industry factors which could be investigated more in the future.

Second, a key finding of the review is the high relevance, for both developed and emerging countries, of policy and regulations, as well as cooperation and the top management commitment to push sustainability implementation. In our view, these elements should, therefore, be put at the centre of future research.

Third, developing countries are still limitedly interested in circular economy models. This represents a pivotal phenomenon to examine. Such a concept should become more widespread also in emerging markets.

Last, digital technology has only partially been adopted in support of sustainability in a global context. This also testifies that the main motives for technology implementation nowadays are related to economic reasons (e.g., efficiency gains, cost reduction, turnover increase), and not sustainability improvements.

Starting from some of the considerations expressed above, the following discussion chapter aims to highlight the key findings of the work and identify possible key topics to be investigated in the future, suggesting the ways in which they could be explored. It should be noted that, in order to define a possible framework for future research, we also referred to literature published on related topics, e.g., internationalisation and global supply chain management, environmental sustainability, and decision making in complex settings. Within this literature, we selected the topics that we considered to be more relevant to the development of global supply chain sustainability research.

\section{Discussion}

\subsection{Summary of Key Findings}

In light of the increasing importance of environmental sustainability in global supply chains, the present paper aimed to systematize the existing literature in this field, and to contribute meaningful suggestions for future research development. The review was conducted considering novel classification factors with respect to existing reviews on similar subjects. More specifically, many existing contributions discuss the evolution of sustainable supply chain practices over time. Conversely, this review observes current practices across different contexts. The 66 contributions retrieved are mainly recent, and were selected following the criteria presented in the attached PRISMA model. All of the contributions, except one book chapter, were published in international journals in the field of supply chains or sustainability. We believe that the number of contributions reviewed in this study is adequate given the focus on a circumscribed set of characteristics. The number of analysed papers is higher than that of previous literature reviews addressing similarly specific topics, e.g., Cagno et al., Perego et al. [86,87]. No previous reviews on the same topic of this study were found in the literature.

The papers were classified based on their industry focus and country focus (developed vs developing markets), as well as their publication year and adopted methods. The possible use of digital technologies was also considered in the presentation of the results. This review was performed mainly for the benefit of scholars and practitioners who are interested in understanding the critical challenges of sustainability management in modern supply chains. The main findings reveal the following insights: 
- Most of the selected papers (41\%) do not have a confined geographical focus.

- All the selected papers have an industry focus, but the automotive, apparel, and food industries are the most represented sectors.

- The research focused on developing countries is less mature, more general, and tends to disregard sustainability assessment aspects.

- The research focused on developed countries presents, in contrast, more details on specific supply chain processes that could be the object of sustainability project implementation.

- Regardless of the analysed country, the majority of the papers highlight the vital role of policy, regulations, top management commitment and inter-organisational collaboration for the success of sustainability initiatives.

- Regardless of the analysed country, the majority of the papers dealing with green initiatives describe a decision setting in which environmental benefits are often an additional consequence, but not the main driver for the implementation of the initiative itself. In many cases, companies implement actions either to improve their economic performances or to comply with regulations. The objective of being environmentally sustainable per se is rarely pursued in current global supply chains.

- Regardless of the analysed country, the majority of the papers do not show a relevant use of new technologies. Since the literature on digital solutions is, however, becoming preeminent, we can infer that such solutions are still used mainly for economic (e.g., higher efficiency), rather than environmental, benefits.

\subsection{Future Research Directions}

In order to overcome the current limitations of global supply chain sustainability studies, we think the following two directions could be followed.

First, there is a need to expand the domain of circular economy practices, and to include emerging economies into this paradigm. The review has revealed that this model is well considered in developed economies [54,55], but has not been analysed in papers focused on developing markets.

Second, the cooperation and the decision-making mechanisms that are more suitable to deal with these global and 'circular' supply chains should be deeply investigated. Indeed, many contributions in literature have highlighted that the managers' commitment towards sustainable practice is key for their effective implementation and success [27,43,44]. However, decision making in sustainability fields is made more complex due to a series of influencing factors, such as the presence (or lack) of policy and regulations pushing towards sustainable behaviour, and the possibility to actually measure the environmental impact of the possible interventions. From this aspect, while developed economies have presented some studies [56-58], developing markets are lagging behind.

One way to foster the diffusion of circular economy practices globally (the first research direction) and analyse their decision-making mechanisms (the second research direction) is to investigate the concept of Intertwined Supply Networks (ISNs), which was recently proposed by Ivanov and Dolgui [88], in the light of environmental sustainability management. The authors of this paper argue that, in the current fast-paced and uncertain environment, taking business decisions at a company or supply chain level is not enough. Indeed, every actor can have different roles (e.g., supplier and buyer simultaneously) or be involved in multiple (global) supply chains with possibly conflicting roles. A supply chain in which each member company does not have a unique position, but rather can take on different roles, is an ISN. We suggest that ISNs become the primary unit of analysis of future studies in this field. This suggestion is in line with the need to develop 'circular' sustainability models involving companies based in different countries.

However, in such complex scenarios, the difficulty of making the right decisions arises, and appropriate decision support tools should be selected. 
Leveraging on the consideration that managers' commitment and decision-making abilities are core for the effective implementation of sustainable practice, we suggest one possible lens to guide future studies in this field, i.e., the cognitive frame approach.

According to Walsh [89], a cognitive frame is a mental template that helps managers make choices when they do not have enough time to grasp the best alternative. Cognitive frames are needed because human minds are not able to analyse the entire range of alternatives in complex scenarios. While cognitive frames are necessary mechanisms, they often prevent one from achieving optimal solutions. Sometimes, managers do not opt for sustainability-centred initiatives because they are too complex, and the results are hard to measure or understand. Their cognitive frames are therefore more biased towards the acceptance of solutions that provide shorter-term, more visible results, but bring only incremental adjustments to supply chain processes instead of real sustainability gains.

Even though the connection between decision-making capabilities and cognitive frames is certain, the research carried out in this field is relatively weak, especially taking a sustainability perspective. To better guide managers, it might be worthwhile to deepen the analysis of this relationship. It would also be interesting to highlight the ways in which different local uses and cultures affect the cognitive frame of their decision-makers, thus comparing the decisional settings of companies in developed and developing countries.

Another connected investigation path regards the factors that could 'enlarge' the cognitive frames of all the people involved in global supply chain sustainability decisions. Several tools can be used for this purpose. For instance, the adoption of new digital technologies could help overcome the limitations of existing cognitive frames. Indeed, digitalisation allows the gathering of information more quickly and safely. It also allows the reduction of the distance between countries [90] contributing to the downsizing of the complexity of ISNs.

We think, therefore, that digital technologies should receive greater attention in this field. This review has revealed that, quite surprisingly, only a limited number of contributions focus on the role of digital technologies. This is a possible signal that companies may be underestimating the environmental benefits of digitisation, while they are mainly considering the economic benefits as decisive factors in the implementation of digital innovation projects. However, digitisation also has a positive influence on ecological aspects in many ways. For instance, IoT technologies can be used to collect more precise and reliable data along all the supply chain phases. Big data analytics tools can be employed to analyse the collected data and use them in the material planning and production phases in order to reduce unbalanced resource consumption, or when planning delivery routes to avoid empty runs and, therefore, reduce $\mathrm{CO}_{2}$ emissions. Data collection and analysis can help identify and understand the more prominent causes of unsustainable practices, support the implementation of corrective measures, and then monitor and measure the effects of the implemented practice over time. Other types of technological solutions, such as cloud-based collaborative platforms or blockchain, provide companies with the opportunity to build stakeholder trust by increasing the visibility of a broader set of actions, including environmentally-oriented ones.

Despite these potential benefits, we must also underline that the implementation of technological solutions to enhance green practice adoption does not come without its obstacles. The barriers to the implementation, for instance, of data collection and sharing systems that are able to operate globally are not only of a technical nature, but also embrace the social, commercial, and legal domains.

To sum up all these considerations, a tentative future research framework and related research questions are offered in Figure 3. 


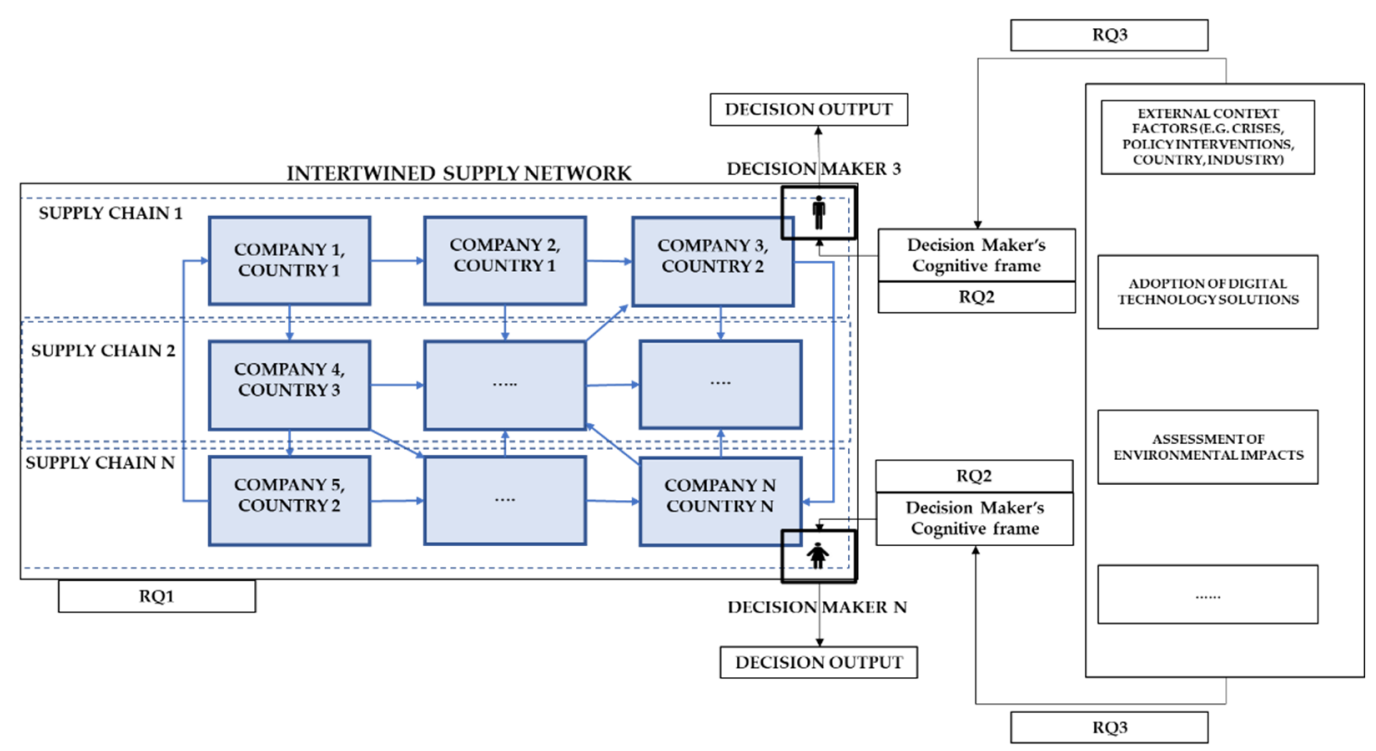

Figure 3. Suggested framework and agenda for future research.

Our review shows that, in order to overcome the main obstacles to a confident implementation of sustainability practices, more informed decision processes are needed.

We believe that future research should try to acknowledge the real complexities affecting environmental sustainability decisions in a global context. Figure 3, above, shows some of the causes of this complexity, namely the increasing interconnections of global supply chains, the fundamental role of key decision-makers, and the factors influencing decision-makers' cognitive frames (i.e., their understanding of the problem) and, consequently, the decision output.

More specifically, the following tentative research questions could be addressed:

- RQ1: What are the possible sustainability practices that can be applied in global ISNs? How can their economic and environmental performances be evaluated? This question goes into the direction of designing research that expands circular economy models on a truly global scale. The same analysis can be repeated for ISNs of different global industries (e.g., food, pharmaceutical, automotive, textile and apparel)

- RQ2: What are the key decision-makers of global ISNs in different industries, and how can they select the best sustainability practices, given the adopted cognitive frames?

- RQ3: What factors (e.g., new policies, organisational structures, new technologies) could influence decision-makers' cognitive frames in this setting?

\section{Conclusions}

This paper provides a detailed overview of the current research outcomes, gaps and possible future directions in the global supply chain sustainability. This work contributes to both the academic and practitioner communities.

From a managerial perspective, this study identifies sustainability initiatives that pertain to different industrial settings and regions, and could be used as references for companies that are interested in the implementation of similar projects. The variety of contests analysed implies that this paper provides practical examples that could be of interest to a broad audience. The paper also underlines the strategic roles of managers and decision makers, as well as their relevance for the success of sustainable initiatives, suggesting that managers should try to set these issues as priorities in their agenda, and that they should try to understand them better.

From an academic perspective, this study gathers the main body of knowledge on supply chain environmental sustainability research in different contexts. The paper also identifies guidelines for 
future research stemming from the main relevant gaps and issues retrieved in the current contributions, and presents them in the discussion section.

We are confident that the identified research lines can positively contribute to the development of a very complex, yet urgent and fascinating research problem: the development of effective and environmentally-oriented decision-making frameworks that consider the complexity of the increasingly intertwined global supply chains.

Author Contributions: Conceptualisation, M.G. and R.M.; methodology, M.G. and R.M.; software, M.G.; validation, M.G. and R.M.; formal analysis, M.G.; investigation, M.G.; data curation, M.G.; writing—original draft preparation, M.G.; writing-review and editing, M.G. and R.M.; supervision, R.M. All authors have read and agreed to the published version of the manuscript.

Funding: This research received no external funding.

Acknowledgments: The authors would like to sincerely thank Eduard Tunica Blancas for his support in the initial steps of the literature search.

Conflicts of Interest: The authors declare no conflict of interest.

\section{Appendix A. PRISMA Flow Diagram}

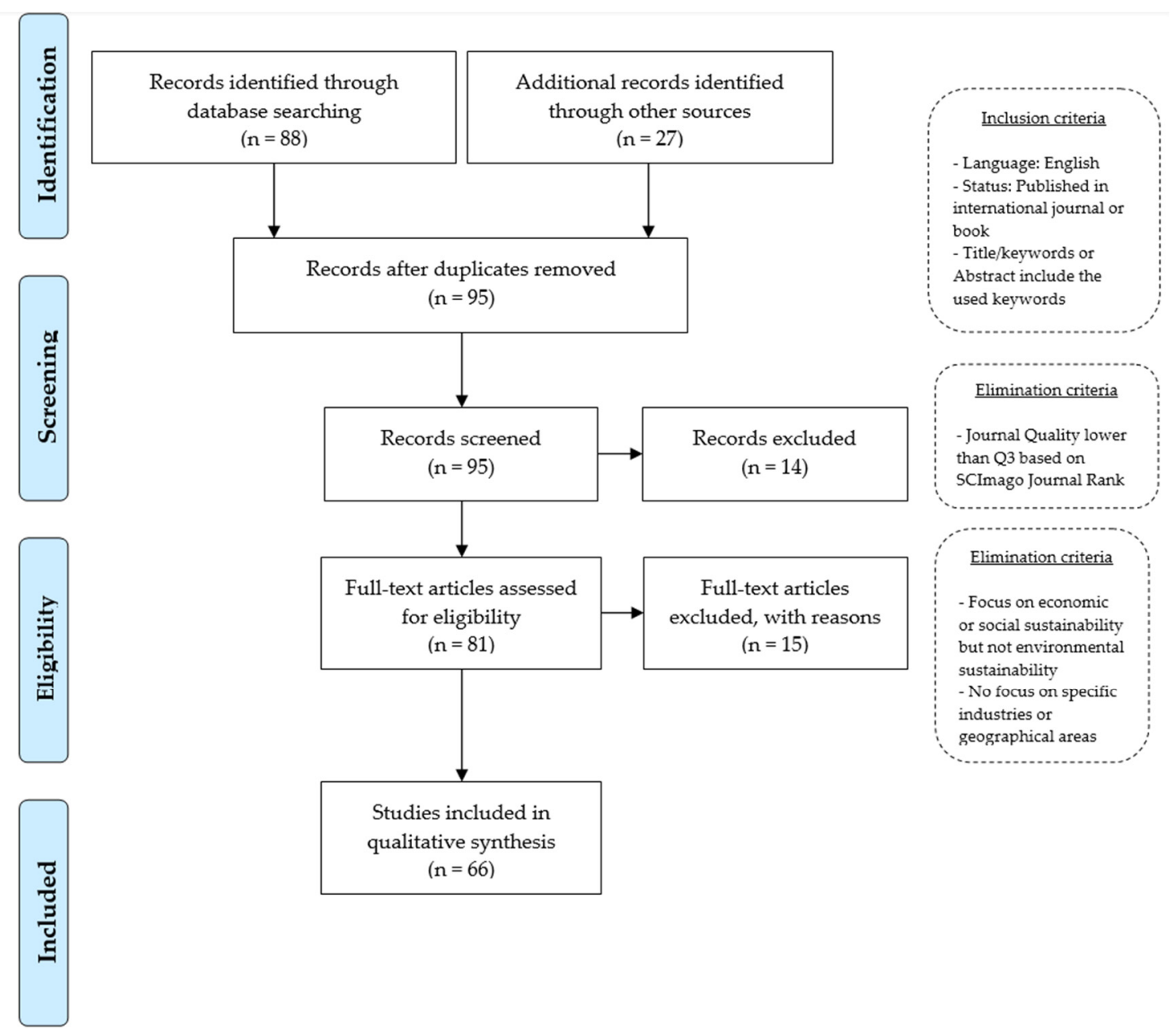

Figure A1. PRISMA Flow Diagram.

\section{References}

1. Hickel, J.; Kallis, G. Is Green Growth Possible? New Political Econ. 2020, 25, 469-486. [CrossRef]

2. Koh, S.C.L.; Gunasekaran, A.; Morris, J.; Obayi, R.; Ebrahimi, S.M. Conceptualising a circular framework of supply chain resource sustainability. Int. J. Oper. Prod. Manag. 2017, 37, 1520-1540. [CrossRef] 
3. Hong, J.; Zhang, Y.; Ding, M. Sustainable supply chain management practices, supply chain dynamic capabilities, and enterprise performance. J. Clean. Prod. 2018, 172, 3508-3519. [CrossRef]

4. Choi, T.Y.; Hong, J. Unveiling the structure of supply networks: Case studies in Honda, Acura, and DaimlerChrysler. J. Oper. Manag. 2002, 20, 469-493. [CrossRef]

5. Wu, Z.; Pullman, M.E. Cultural embeddedness in supply networks. J. Oper. Manag. 2015, 37, 45-58. [CrossRef]

6. Koberg, E.; Longoni, A. A systematic review of sustainable supply chain management in global supply chains. J. Clean. Prod. 2019, 207, 1084-1098. [CrossRef]

7. Rajeev, A.; Pati, R.K.; Padhi, S.S.; Govindan, K. Evolution of sustainability in supply chain management: A literature review. J. Clean. Prod. 2017, 162, 299-314. [CrossRef]

8. Ahmadi, H.B.; Lo, H.W.; Gupta, H.; Kusi-Sarpong, S.; Liou, J.J.H. An integrated model for selecting suppliers on the basis of sustainability innovation. J. Clean. Prod. 2020, 277, 1-11. [CrossRef]

9. Ebinger, F.; Omondi, B. Leveraging digital approaches for transparency in sustainable supply chains: A conceptual paper. Sustainability 2020, 12, 6129. [CrossRef]

10. Mitra, A.; Gaur, S.S. Does environmental concern drive Asian firms' governance? J. Asia Bus. Stud. 2020, 14, 481-503. [CrossRef]

11. Giuffrida, M.; Mangiaracina, R.; Miragliotta, G.; Perotti, S.; Tumino, A. Modelling the environmental impact of omni-channel purchasing in the apparel industry: The role of logistics. Int. J. Logist. Syst. Manag. 2019, 34, 431-456. [CrossRef]

12. Schneider, S. The Impacts of Digital Technologies on Innovating for Sustainability. In Innovation for Sustainability; Bocken, N., Ritala, P., Albareda, L., Verburg, R., Eds.; Palgrave Macmillan: Cham, Switzerland, 2019; pp. 415-433. [CrossRef]

13. Tranfield, D.R.; Denyerand, D.; Smart, P. Towards a methodology for developing evidence-informed management knowledge by means of systematic review. Br. J. Manag. 2003, 14, 207-222. [CrossRef]

14. World Bank. World Development Report 2016: Digital Dividends; World Bank: Washington, DC, USA, 2016.

15. Sustainable Development Goals. Available online: sdgs.un.org (accessed on 18 October 2020).

16. Giuffrida, M.; Mangiaracina, R.; Perego, A.; Tumino, A. Cross-border B2C e-commerce to Greater China and the role of logistics: A literature review. Int. J. Phys. Distrib. Logist. Manag. 2017, 47, 772-795. [CrossRef]

17. Ren, R.; Hu, W.; Dong, J.; Sun, B.; Chen, Y.; Chen, Z. A Systematic Literature Review of Green and Sustainable Logistics: Bibliometric Analysis, Research Trend and Knowledge Taxonomy. Int. J. Environ. Res. Public Health 2019, 17, 261. [CrossRef]

18. Tasdemir, C.; Gazo, R. A Systematic Literature Review for Better Understanding of Lean Driven Sustainability. Sustainability 2018, 10, 2544. [CrossRef]

19. Geissdoerfer, M.; Pieroni, M.P.P.; Pigosso, D.C.A.; Soufani, K. Circular business models: A review. J. Clean. Prod. 2020, 277, 123741. [CrossRef]

20. Sánchez-Flores, R.B.; Cruz-Sotelo, S.E.; Ojeda-Benitez, S.; Ramirez-Barreto, M.E. Sustainable Supply Chain Management-A Literature Review on Emerging Economies. Sustainability 2020, 12, 6972. [CrossRef]

21. Wohlin, C. Guidelines for snowballing in systematic literature studies and a replication in software engineering. In Proceedings of the 18th International Conference on Evaluation and Assessment in Software Engineering, London, UK, 13-14 May 2014; pp. 1-10.

22. European Green Deal. Available online: ec.europa.eu/info/strategy/priorities-2019-2024/european-greendeal_it (accessed on 19 October 2020).

23. World Economic Forum, The War on Plastic: 5 Green Laws for 2020. Available online: weforum.org/agenda/ 2020/01/green-laws-environment-2020/ (accessed on 19 October 2020).

24. Meixell, M.J.; Norbis, M. A review of the transportation mode choice and carrier selection literature. Int. J. Logist. Manag. 2008, 19, 183-211. [CrossRef]

25. Lu, B.; Yang, J.; Ijomah, W.; Wu, W.; Zlamparet, G. Perspectives on reuse of WEEE in China: Lessons from the EU. Resour. Conserv. Recycl. 2018, 135, 83-92. [CrossRef]

26. Kusch-Brandt, S. Towards More Sustainable Food Systems-14 Lessons Learned. Int. J. Environ. Res. Public Health 2020, 17, 4005. [CrossRef]

27. Chikudza, L.; Gauzente, C.; Guillotreau, P.; Alexander, K.A. Producer perceptions of the incentives and challenges of adopting ecolabels in the European finfish aquaculture industry: A Q-methodology approach. Marine Policy 2020, 104176. [CrossRef] 
28. Castro-Nunez, A.; Charry, A.; Castro-Llanos, F.; Sylvester, J.; Bax, V. Reducing deforestation through value chain interventions in countries emerging from conflict: The case of the Colombian cocoa sector. Appl. Geogr. 2020, 123, 102280. [CrossRef]

29. Wiedemann, S.G.; Biggs, L.; Nebel, B.; Bauch, K.; Laitala, K.; Klepp, I.G.; Swan, P.G.; Watson, K. Environmental impacts associated with the production, use, and end-of-life of a woollen garment. Int. J. Life Cycle Assess. 2020, 25, 1486-1499. [CrossRef]

30. Wong, S.K.S. Environmental Requirements, Knowledge Sharing and Green Innovation: Empirical Evidence from the Electronics Industry in China. Bus. Strategy Environ. 2012, 5, 321-338. [CrossRef]

31. Messner, R.; Richards, C.; Johnson, H. The "Prevention Paradox": Food waste prevention and the quandary of systemic surplus production. Agric. Hum. Values 2020, 37, 805-817. [CrossRef]

32. Cioca, L.I.; Ivascu, L.; Turi, A.; Artene, A.; Găman, G.A. Sustainable Development Model for the Automotive Industry. Sustainability 2019, 11, 6447. [CrossRef]

33. Evans, R.; Vermeulen, W.J. Governing Electronics Sustainability: Meta-evaluation of explanatory factors influencing modes of governance applied in the electronics value chain. J. Clean. Prod. 2020, 122952. [CrossRef]

34. Patil, R.A.S.; Ramakrishna, S. A comprehensive analysis of e-waste legislation worldwide. Environ. Sci. Pollut. Res. 2020, 27, 14412-14431. [CrossRef]

35. Kumar, A.; Holuszko, M.; Crocce, D.; Espinosa, R. E-waste: An overview on generation, collection, legislation and recycling practices. Resources Conserv. Recycl. 2017, 122, 32-42. [CrossRef]

36. Bernecker, T.; Lohre, D.; Poerschke, V.; Roth, J.; Grandjot, H.H. Sustainable Logistics. In An Introduction to the Concept and Case Studies from Germany; Deutsche Gesellschaft fur Internationale Zusammenarbeit (Giz) Gmbh and German Partnership for Sustainable Mobility: Bonn, Germany, 2015; pp. 1-60.

37. Villa, B.; Nogueira, M.; Fleith, J. Collaboration practices in the fashion industry: Environmentally sustainable innovations in the value chain. Environ. Sci. Policy 2020, 106, 1-11. [CrossRef]

38. Pacheco, P.; Schoneveld, G.; Dermawan, A.; Komarudin, H.; Djama, M. Governing sustainable palm oil supply: Disconnects, complementarities, and antagonisms between state regulations and private standards. Regul. Gov. 2020, 14, 568-598. [CrossRef]

39. Jeong, H.J.; Ko, Y. Configuring an alliance portfolio for eco-friendly innovation in the car industry: Hyundai and Toyota. J. Open Innov. Technol. Mark. Complex. 2016, 2. [CrossRef]

40. Chavez, R.; Sharma, M. Profitability and environmental friendliness of a closed-loop supply chain for PET components: A case study of the Mexican automobile market. Resour. Conserv. Recycl. 2017, 135, 172-189. [CrossRef]

41. Bryceson, K.P.; Ross, A. Agrifood chains as complex systems and the role of informality in their sustainability in small scale societies. Sustainability 2020, 12, 6535. [CrossRef]

42. Bhaskar, K.; Turaga, R.M.R. India's E-waste rules and their impact on E-waste management practices a case study. J. Ind. Ecol. 2018, 22, 930-942. [CrossRef]

43. Law, K.M.; Gunasekaran, A. Sustainability development in high-tech manufacturing firms in Hong Kong: Motivators and readiness. Int. J. Prod. Econ. 2012, 137, 116-125. [CrossRef]

44. Kumar, N.; Mathiyazhagan, K.; Mathivathanan, D. Modelling the interrelationship between factors for adoption of sustainable lean manufacturing: A business case from the Indian automobile industry. Int. J. Sustain. Eng. 2020, 13, 93-107. [CrossRef]

45. Cardoso De Oliveira Neto, G.; Nieves Pujol Tucci, H.; Ferreira Correia, J.M.; Da Silva, P.C.; Carlquist da Silva, V.H.; Miller Devós Ganga, G. Assessing the implementation of Cleaner Production and company sizes: Survey in textile companies. J. Eng. Fiber. Fabr. 2020. [CrossRef]

46. Cardoso De Oliveira Neto, G.; Ferreira Correia, J.M.; Da Silva, P.C.; De Olivares Sanches, A.G.; Wagner Cezar, L. Cleaner Production in the textile industry and its relationship to sustainable development goals. J. Clean. Prod. 2019, 228. [CrossRef]

47. Khattak, A.; Stringer, C.; Benson-rea, M.; Haworth, N. Environmental upgrading of apparel firms in global value chains: Evidence from Sri Lanka. Compet. Chang. 2015. [CrossRef]

48. Abbas, S.; Chiang Hsieh, L.H.; Techato, K.; Taweekun, J. Sustainable production using a resource e energy e water nexus for the Pakistani textile industry. J. Clean. Prod. 2020, 271, 122633. [CrossRef]

49. Li, J. Charging Chinese future: The roadmap of China's policy for new energy automotive industry. Int. J. Hydrogen Energy 2020, 45, 11409-11423. [CrossRef] 
50. Choi, Y.; Rhee, S.W. Current status and perspectives on recycling of end-of-life battery of electric vehicle in Korea (Republic of). Waste Manag. 2020, 106, 261-270. [CrossRef]

51. Ben, R.; Vinodh, S.; Asokan, P. Implementation of Lean Six Sigma framework with environmental considerations in an Indian automotive component manufacturing firm: A case study. Prod. Plan. Control. 2017, 28, 1193-1211. [CrossRef]

52. Veleva, V.R.; Cue, B.W., Jr.; Todorova, S.; Mehta, N.H.; Padia, K.B. Benchmarking green chemistry adoption by the Indian pharmaceutical supply chain. Green Chem. Lett. Rev. 2018, 8253. [CrossRef]

53. Kaczan, D.J.; Patil, P.G. Potential Development Contribution of Fisheries Reform: Evidence from Pakistan. J. Environ. Dev. 2020, 29, 275-305. [CrossRef]

54. Gazzola, P.; Pavione, E.; Pezzetti, R.; Grechi, D. Trends in the Fashion Industry. The Perception of Sustainability and Circular Economy: A Gender/Generation Quantitative Approach. Sustainability 2020, 12, 2809. [CrossRef]

55. Moore, E.A.; Russell, J.D.; Babbitt, C.W.; Tomaszewski, B.; Clark, S.S. Spatial modeling of a second-use strategy for electric vehicle batteries to improve disaster resilience and circular economy. Resour. Conserv. Recycl. 2020, 160, 104889. [CrossRef]

56. Schiessl, A.; Müller, R.; Volk, R.; Zimmer, K.; Breun, P.; Schultmann, F. Integrating site-specific environmental impact assessment in supplier selection: Exemplary application to steel procurement. J. Bus. Econ. 2020, 1-49. [CrossRef]

57. Bobba, S.; Mathieux, F.; Ardente, F.; Blengini, G.A.; Cusenza, M.A.; Podias, A.; Pfrang, A. Life Cycle Assessment of repurposed electric vehicle batteries: An adapted method based on modelling energy flows. J. Energy Storage 2018, 213-225. [CrossRef]

58. Mair-Bauernfeind, C.; Zimek, M.; Asada, R.; Bauernfeind, D.; Baumgartner, R.J.; Stern, T. Prospective sustainability assessment: The case of wood in automotive applications. Int. J. Life Cycle Assess. 2020, 25, 2027-2049. [CrossRef]

59. Curwen, L.G.; Park, J.; Sarkar, A.K. Challenges and Solutions of Sustainable Apparel Product Development: A Case Study of Eileen Fisher. Cloth. Text. Res. J. 2012, 31, 32-47. [CrossRef]

60. De Marchi, V.; Di Maria, E. Environmental Upgrading and Suppliers' Agency in the Leather Global Value Chain. Sustainability 2019, 11, 6530. [CrossRef]

61. Beier, G.; Kiefer, J.; Knopf, J. Potentials of big data for corporate environmental management: A case study from the German automotive industry. J. Ind. Ecol. 2020, 9, 1-14. [CrossRef]

62. Wei, F.; Alias, C.; Noche, B. Applications of Digital Technologies in Sustainable Logistics and Supply Chain Management. In Innovative Logistics Services and Sustainable Lifestyles; Springer: Cham, Switzerland, 2019; pp. 235-263.

63. Fulton, K.; Lee, S.E. Assessing sustainable initiatives of apparel retailers on the internet. J. Fash. Mark. Manag. Int. J. 2013, 17, 353-366. [CrossRef]

64. Prosperi, P.; Vergamini, D.; Bartolini, F. Exploring institutional arrangements for local fish product labelling in Tuscany (Italy): A convention theory perspective. Agric. Food Econ. 2020, 8. [CrossRef]

65. Veleva, V. Benchmarking green chemistry adoption by 'big pharma' and generics manufacturers. Benchmarking Int. J. 2016. [CrossRef]

66. Ghosh, A. Possibilities and challenges for the inclusion of the Electric Vehicle (EV) to reduce the carbon footprint in the transport sector: A review. Energies 2020, 13, 2602. [CrossRef]

67. Kalverkamp, M.; Young, S.B. In support of open-loop supply chains: Expanding the scope of environmental sustainability in reverse supply chains. J. Clean. Prod. 2019, 214, 573-582. [CrossRef]

68. Kalverkamp, M. Hidden potentials in open-loop supply chains for remanufacturing. Int. J. Logist. Manag. 2018, 29, 1125-1146. [CrossRef]

69. Cherny-Scanlon, X. Putting glam into green: A case for sustainable luxury fashion. In Spirituality and Sustainability; Springer: Cham, Switzerland, 2016; pp. 183-197.

70. Shirvanimoghaddam, K.; Motamed, B.; Ramakrishna, S.; Naebe, M. Death by waste: Fashion and textile circular economy case. Sci. Total Environ. 2020, 718, 137317. [CrossRef] [PubMed]

71. Ferreira, J.M.; Da silva, P.C.; Cardoso, G.; Nieves, H. Evaluation of economic, environmental and operational performance of the adoption of cleaner production: Survey in large textile industries. J. Clean. Prod. 2020, 278. [CrossRef]

72. Kushwaha, G.S.; Sharma, N.K. Green initiatives: A step towards sustainable development and firm's performance in the automobile industry. J. Clean. Prod. 2016, 121, 116-129. [CrossRef] 
73. Farias, L.M.S.; Santos, L.C.; Gohr, C.F.; de Oliveira, L.C.; da Silva Amorim, M.H. Criteria and practices for lean and green performance assessment: Systematic review and conceptual framework. J. Clean. Prod. 2019, 218, 746-762. [CrossRef]

74. Cucchiella, F.; D'Adamo, I.; Rosa, P.; Terzi, S. Automotive printed circuit boards recycling: An economic analysis. J. Clean. Prod. 2016, 121, 130-141. [CrossRef]

75. Cherrafi, A.; Elfezazi, S.; Hurley, B.; Garza-Reyes, J.A.; Kumar, V.; Anosike, A.; Batista, L. Green and lean: A Gemba-Kaizen model for sustainability enhancement. Prod. Plan. Control. 2019, 30, 385-399. [CrossRef]

76. Veleva, V.R.; Cue, B.W., Jr. The role of drivers, barriers, and opportunities of green chemistry adoption in the major world markets. Curr. Opin. Green Sustain. Chem. 2019, 19, 30-36. [CrossRef]

77. Veleva, V.R.; Cue, B.W., Jr.; Todorova, S. Benchmarking Green Chemistry Adoption by the Global Pharmaceutical Supply Chain. ACS Sustain. Chem. Eng. 2018. [CrossRef]

78. Koenig, S.G.; Bee, C.; Borovika, A.; Briddell, C.; Colberg, J.; Humphrey, G.R.; Kopach, M.E.; Martinez, I.; Nambiar, S.; Plummer, S.V. A Green Chemistry Continuum for a Robust and Sustainable Active Pharmaceutical Ingredient Supply Chain. ACS Sustain. Chem. Eng. 2019. [CrossRef]

79. Dranev, Y.; Izosimova, A.; Meissner, D. Organisational ambidexterity and performance: Assessment approaches and empirical evidence. J. Knowl. Econ. 2020, 11, 676-691. [CrossRef]

80. Rane, S.B.; Thakker, S.V.; Kant, R. Stakeholders' involvement in green supply chain: A perspective of blockchain IoT-integrated architecture. Manag. Environ. Qual. Int. J. 2020. [CrossRef]

81. Rahman, M.; Billah, M.; Hack-polay, D.; Alam, A. The use of biotechnologies in textile processing and environmental sustainability: An emerging market context. Technol. Forecast. Soc. Chang. 2020, 159, 120204. [CrossRef]

82. Arvanitis, K.G.; Symeonaki, E.G. Agriculture 4.0: The Role of Innovative Smart Technologies Towards Sustainable Farm Management. Open Agric. J. 2020, 14, 130-135. [CrossRef]

83. Ahmad, S.; Miskon, S.; Alabdan, R.; Tlili, I. Towards Sustainable Textile and Apparel Industry: Exploring the Role of Business Intelligence Systems in the Era of Industry 4.0. Sustainability 2020, 12, 2632. [CrossRef]

84. Sjödin, D.R.; Parida, V.; Leksell, M.; Petrovic, A. Smart Factory Implementation and Process Innovation. Res. Technol. Manag. 2018, 61, 22-31. [CrossRef]

85. Yadav, G.; Luthra, S.; Jakhar, S.K.; Mangla, S.K.; Rai, D.P. A framework to overcome sustainable supply chain challenges through solution measures of industry 4.0 and circular economy: An automotive case. J. Clean. Prod. 2020, 254, 120112. [CrossRef]

86. Cagno, E.; Micheli, G.J.L.; Masiand, D.; Jacinto, C. Economic evaluation of OSH and its way to SMEs: A constructive review. Saf. Sci. 2013, 53, 134-152. [CrossRef]

87. Perego, A.; Perotti, S.; Mangiaracina, R. ICT for logistics and freight transportation: A literature review and research agenda. Int. J. Phys. Distrib. Logist. Manag. 2011, 41, 457-483. [CrossRef]

88. Ivanov, D.; Dolgui, A. Viability of intertwined supply networks: Extending the supply chain resilience angles towards survivability. A position paper motivated by COVID-19 outbreak. Int. J. Prod. Res. 2020, 58, 2904-2915. [CrossRef]

89. Walsh, J.P. Managerial and organisational cognition: Notes from a trip down memory lane. Organ. Sci. 1995, 6, 280-321. [CrossRef]

90. Kayikci, Y. Sustainability impact of digitisation in logistics. Procedia Manuf. 2018, 21, 782-789. [CrossRef]

Publisher's Note: MDPI stays neutral with regard to jurisdictional claims in published maps and institutional affiliations.

(C) 2020 by the authors. Licensee MDPI, Basel, Switzerland. This article is an open access article distributed under the terms and conditions of the Creative Commons Attribution (CC BY) license (http://creativecommons.org/licenses/by/4.0/). 